\title{
Palaeoenvironmental significance of middle Oxfordian deep marine deposits from La Manga Formation, Neuquén Basin, Argentina
}

\author{
R.M. Palma ${ }^{1 *}$, G.S. Bressan ${ }^{1}$, D.A. Kietzmann¹, A.C. Riccardi², J. Martín-Chiveletet,4, J. López- Gómez \\ ${ }^{1}$ Universidad de Buenos Aires, Facultad de Ciencias Exactas y Naturales, Departamento de Ciencias Geológicas - CONICET \\ (IDEAN), 1428 Buenos Aires, Argentina. \\ ${ }^{2}$ Facultad de Ciencias Naturales y Museo, Universidad Nacional de La Plata, Paseo del Bosque s/n. 1900 La Plata, Argentina \\ ${ }^{3}$ Departamento de Estratigrafia, Facultad de Ciencias Geológicas, Universidad Complutense de Madrid, 28040 Madrid, Spain. \\ ${ }^{4}$ Instituto de Geociencias IGEO (CSIC,UCM), C. José Antonio Nováis 12, 28040 Madrid, Spain.
}

e-mailaddresses:palma@gl.fcen.uba.ar(R.M.P., correspongingauthor); gbressan@gl.fcen.uba.ar (G.S.B.); diegokietzmann@gl.fcen.uba.ar (D.A.K.); riccardi@ museo.fcnym.unlp.edu.ar (A.C.R.); j.m.chivelet@geo.ucm.es (J.M.-C.); jlopez@geo.ucm.es (J.L-G.)

Received: 20 November 2013 / Accepted: 30 June 2014 / Available online: 30 October 2014

\begin{abstract}
The Callovian-Oxfordian of the Neuquén Basin (Argentina) is characterized by an extensive marine carbonate system (La Manga Formation) with a predominance of shallow and middle ramp deposits, although locally in tectonically controlled settings, deeper deposits also formed. These middle Oxfordian deeper deposits consist of mudstone-wackestone carbonates alternating with black shales and show marked centimetre-scale rhythmicity, probably controlled by the Earth's orbit parameters, mainly precession and eccentricity. The present study was designed to examine these deposits in terms of their sedimentology, geochemistry, and small-scale stratigraphy in Arroyo Los Blancos, southern Mendoza Province, where they are exceptionally well exposed and preserved. Results indicate that the sediments were deposited in an anoxic to dysoxic, relatively deep, sea-floor environment as revealed by the presence of: a) organic-rich shales, b) undisrupted lamination in most facies, c) pyrite framboids, and d) absence or scarcity of trace fossils and benthic fauna. Thin beds of graded wackestone-packstone and accumulations of thin shells of Bositra bivalves indicate sporadic reworking of the sea floor by weak currents. Organic petrology, Rock-Eval pyrolysis and thermal maturity indicators were used to characterize TOC and different types of organic matter. Low pyrolysis S yields along with low hydrogen indices suggest poor kerogen convertibility. Vitrinite reflectance (\%Ro) ranged from 2.39 to 2.97 with an average of 2.70 . The thermal alteration index (TAI) was 4+(5), indicating overmaturity. A tectono-sedimentary model is proposed for these deposits. According to this model, the relatively deep, organic-matter rich facies of La Manga Formation would have been deposited in the deepest zones of topographic lows controlled by tilting and differential subsidence of tectonic blocks bounded by normal faults. These faults were probably inherited from previous extensional tectonics of Late Triassic - Early Jurassic age.
\end{abstract}

Keywords: Hemipelagic, middle Oxfordian, TOC, Cylostratigraphy, Neuquén Basin

Resumen

El Calloviense-Oxfordiense en el norte de la Cuenca Neuquina (Argentina) estuvo caracterizado por el desarrollo de un amplio sistema de rampa carbonatada (Formación La Manga) en el que predominaron los depósitos de rampa media y somera aunque localmente, y debido a control tectónico, pudieron acumularse depósitos más profundos. Estos depósitos, de edad Oxfordiense medio, están expuestos y preservados excepcionalmente en la zona de Arroyo Los Blancos, al sur de la provincia de Mendoza, y su estudio sedimentológico, geoquímico y estratigráfico representan el objetivo de este trabajo. Consisten en carbonatos (mudstone-wackestone) con acumulaciones de finas conchas de bivalvos de tipo Bositra que indican retrabajamientos esporádicos del sustrato marino debido a corrientes de baja intensidad. Se han caracterizado diferentes tipos de materia orgánica y TOC mediante petrología orgánica, Rock-Eval Pyrolisis e indicadores de madurez térmica. Los bajos valores en el campo del S unido al también bajo índice de H sugieren una baja convertibilidad de Kerógeno. La reflectancia de la vitrinita (\%Ro) tiene un rango que oscila entre 2,39 y 2,97, con una media de 2,70, mientras que el índice de alteración térmico (TAI) es de 4+(5) indicando sobremaduración. Se propone también un modelo tectono-sedimentario para estos depósitos. En este modelo, estas facies relativamente profundas y ricas en materia orgánica de la Formación La Manga estarían depositadas en la parte más deprimida de bajos topográficos controlados por una subsidencia diferencial y de pulsos en bloques marcados por fallas normales heredadas probablemente de una tectónica extensional durante el Triásico Superior-Jurásico Inferior. 


\section{Introduction}

The Callovian-Oxfordian in the Neuquén Basin (Argentina) was a time of widespread carbonate deposition that is recorded in La Manga Formation. These deposits include outer carbonate ramp, middle ramp, inner ramp margin (patch reef), and inner ramp facies (Legarreta, 1991; Palma et al., 2007, 2009, 2011, 2013). Due to economic interests, these carbonate ramp sediments have been extensively investigated and many sequence stratigraphic and palaeogeographical data are available (Mitchum and Uliana, 1985; Legarreta and Uliana, 1996; among others). However, the deep distal outer ramp or basin deposits of this formation have been scarcely addressed, probably because they were represented by only a few, discontinuous outcrops. This situation changed with the discovery of an exceptional outcrop of these deep facies of La Manga Formation in Arroyo Los Blancos (southern Mendoza Province).

The goal of this work is to discuss the depositional environment of the Los Blancos section. Since field data are not abundant enough to construct precise geometries of these deepwater deposits because of the scarcity of outcrops, an intense microstratigraphic work has been done to describe in detail the sedimentary succession. The work reported here includes analysis of facies/microfacies, carbonate contents, TOC fluctuations, and cyclostratigraphy. In fact, the vertical arrangement of the facies allows the identification of rhythmic recurrence. This paper is the first referred to estimate the periodicies of the rhythms for the middle Oxfordian deep carbonate deposits in Argentina.

\section{Geological setting}

The Neuquén Basin is a vast oil- and gas-bearing basin located in west-central Argentina and eastern Chile between $31^{\circ} \mathrm{S}$ and $41^{\circ} \mathrm{S}$ (Figs. 1A, B). The basin's infill, developed between Upper Triassic to Paleocene, includes 4000 to 7000 $\mathrm{m}$ of marine and continental strata (Vergani et al., 1995; Legarreta and Uliana, 1996). The sedimentary record mostly consists of shallow marine deposits reflecting the basin's connection with the Palaeo-Pacific Ocean, though periodical interruptions of this connection due to sea level falls are commonly registered (Legarreta and Uliana, 1996).

The basin's Jurassic deposits form part of the Lower Supersequence of Legarreta and Gulisano (1989), which includes three mesosequences: Precuyo, Cuyo, and Lotena (Fig. 1C). The Lotena mesosequence, lower Callovian to upper Oxfordian-Kimmeridgian in age (Legarreta, 1991; Palma et al., 2012), comprises five depositional sequences (Fig. 1D) that include marine and continental facies (Lotena Formation), carbonate deposits (La Manga Formation), and evaporites (Auquilco Formation).

This paper focuses on the deepest facies of La Manga Formation. These facies, mentioned in regional papers (e.g., Legarreta, 1991) and exploration works (e.g., Stipanicic, 1966) have received little attention, most likely because of a lack of good outcrops. However, they may be considered ideal for understanding the processes occurring in the basin at the time of their deposition. The Arroyo Los Blancos outcrop is an exceptionally well exposed and preserved succession of these deep facies of La Manga Formation. The outcrop in the southern Mendoza Province (Argentina) lies $5 \mathrm{~km}$ east of the village of Los Molles and is close to the Salado River (Fig. 1B). In that locality, La Manga Formation is 33 $\mathrm{m}$ thick and consists of a cm-scale rhythmic alternation of mudstone-wackestone carbonates and black-shales (Fig. 2A). Macrofossils are scarce but its well-preserved ammonites (Perisphinctes (Arisphinctes?) sp., Perisphinctes-Araucanites Zone) have served to allocate the section to the middle Oxfordian (Riccardi, 2008).

It should be mentioned that deposits laterally equivalent to those of Arroyo Los Blancos, but consisting of much shallower facies, occur in the proximities of the section under study (Palma et al., 2013) and contain specimens of Mirosphinctes sp. (middle Oxfordian). Also, these shallower facies are similar to those observed in the upper part of $\mathrm{La}$ Manga Formation in the localities of Yeseras Grandes and Arroyo La Manga, and are interpreted as intertidal-supratidal deposits (Palma et al., 2012, 2013).

Due to the quality of the outcrops, their stratigraphic position and their well established ages, the Los Blancos deposits constitute a critical sedimentary section in the study of these deep marine jurassic deposits.

Drilling carried out by YPF S.A. on the Jurassic marine deposits in the Neuquén province has demonstrated the presence of limestones and shales interbedded with thin layers of siltstones and sandstones attributed to the Barda Negra Formation (Digregorio, 1965). Based on their ammonite fauna content and their stratigraphic relationships, these rocks may be correlated with the La Manga Formation (Stipanicic, 1966) and sedimentological and biostratigraphical data can be extrapolated to the neighbouring areas in the Neuquén Basin, where these aspects of the geological record are covered or poorly documented. A similar facies pattern seems to have developed in the Bardas Blancas area where deep deposits are mentioned by Legarreta (1991). Unfortunately, no sedimentological studies have been performed on these deep facies.

The study area is located within the "Atuel depocenter" of the Neuquén Basin. This area records the first stages of the opening of the basin during Triassic to Jurassic times in response to regional extension processes (Legarreta and Uliana, 1996).

\section{Methodology}

The depositional environment was inferred from facies and microfacies analyses at the Arroyo Los Blancos section. Bed thickness, bed geometry, grain size and sedimentary structure were determined in the field.

Cyclostratigraphic analysis is based on the differentiation of centimetre-scale couplets of carbonate/siliciclastic litho- 

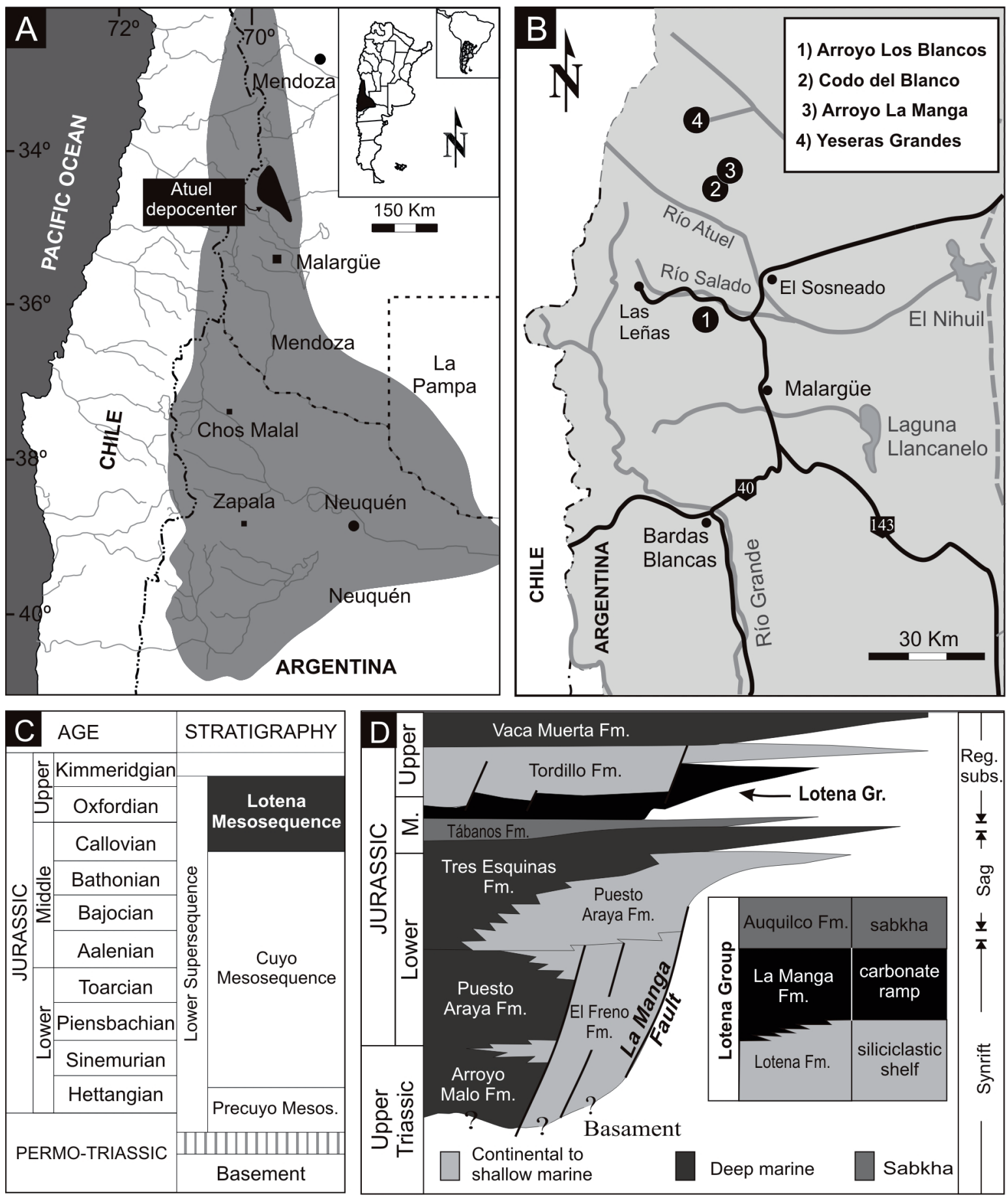

Fig. 1.- A. Location map of the Neuquén Basin with indication of the Atuel depocenter. B. Location map showing the position of localities of La Manga Formation: (1) Arroyo Los Blancos; (2) Codo del Blanco; (3) Arroyo La Manga; (4) Yeseras Grandes. C. Lower Mesosequence chronostratigraphic framework (modified from Legarreta and Gulisano, 1989). D. Jurassic lithostratigraphy of the Neuquén Basin in the Atuel depocenter, south of the Mendoza province (after Giambiagi et al., 2008).

facies or elementary cycles. Lower frequencies were identified through spectral analysis with the software POWGRAF2 (Pardo-Igúzquiza and Rodríguez-Tovar, 2004) using the Blackman-Tukey method. The biozonation scheme used in this study is that described by Riccardi (2008).

At the Universidad Complutense de Madrid (UCM), sediment samples were analyzed as thin sections by X-ray diffraction (XRD) for a semiqualitative overview of whole rock and clay mineralogy. To distinguish different minerals, samples were also subjected to cold cathodoluminescence microscopy (Technosym) at $14-17 \mathrm{kV}$ with $350-450 \mu \mathrm{A}$ beam current at the Stratigraphy Department of the UCM.

At the Universidad de Buenos Aires (Centro de Microscopía Electrónica, Facultad de Ciencias Exactas y Naturales), fresh broken sediment surfaces and polished carbon coated thin sections were examined by scanning electronic 


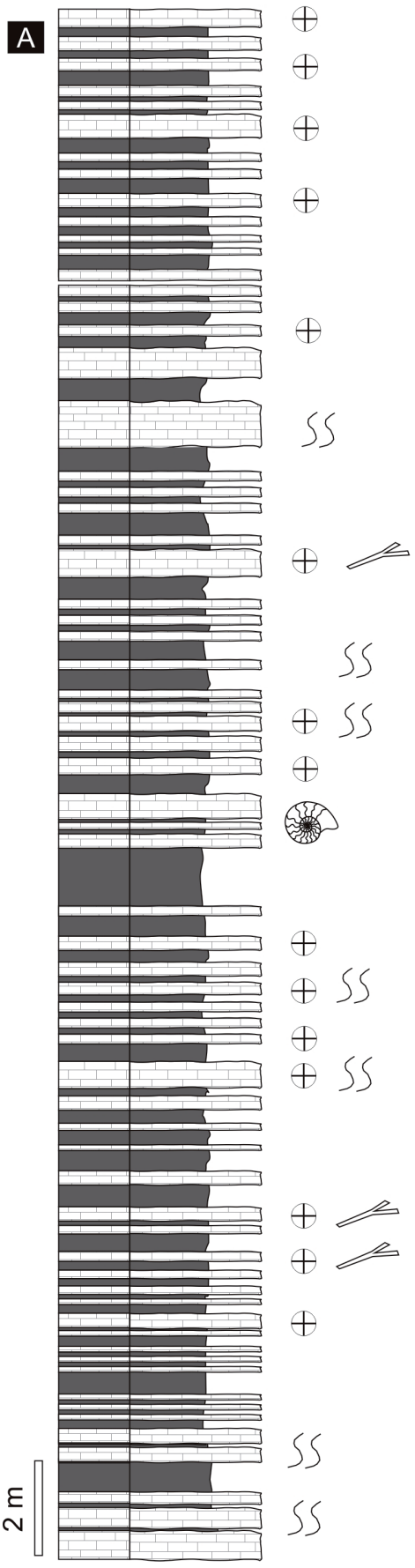

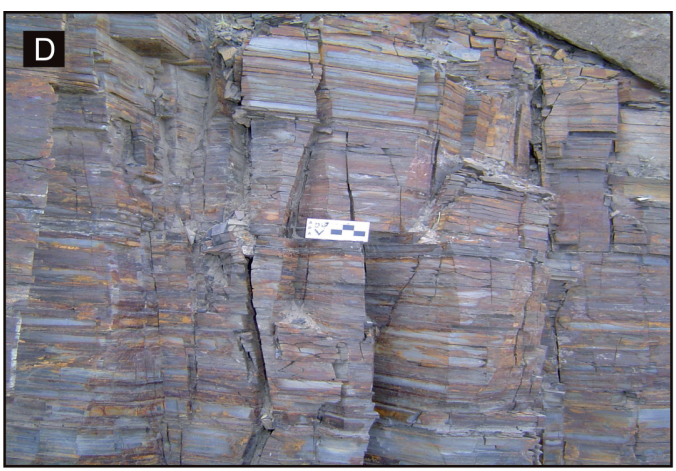
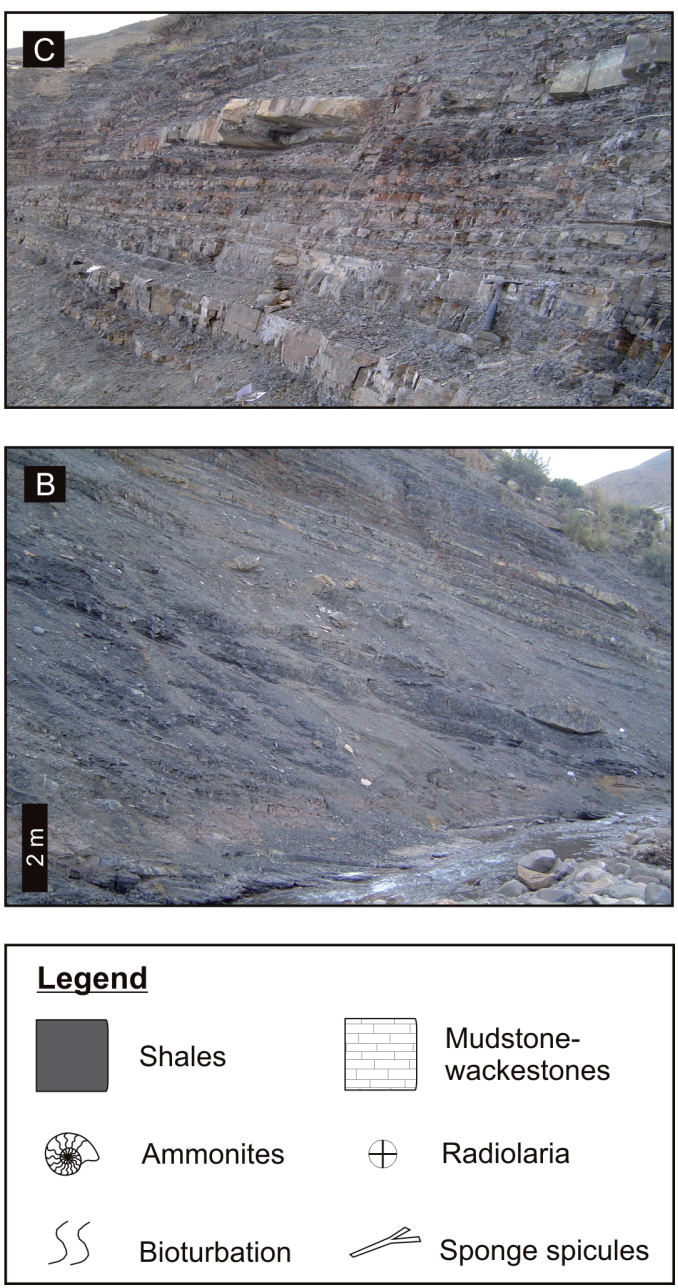

Fig. 2.- A. Lithological log of the studied section indicating texture and fossil contents. For discussion refer to text. B-D. Outcrop photographs of representative facies of the Los Blancos section. B. General view of black shales facies in the lower section; C. Detailed view of laminated lime-mudstones. D. Detailed view of laminated wackestones. microscopy (SEM) using a Zeiss (Supra 40) microscope and an Oxford Instrument EDS energy dispersive spectroscopy detector (INCA).

Rock-Eval pyrolisis methods were used to estimate total organic carbon (TOC) and the source and thermal maturity of organic matter (Espitalié et al., 1985). These procedures were performed at GeoLab Sur (Geochemical Laboratory) in Buenos Aires.

\section{Facies}

Descriptions and interpretations of facies of La Manga Formation in Arroyo Los Blancos were based on lithol- ogy, colour and internal structures. These descriptions were completed with the study of microfacies, carbonate contents and organic carbon contents. According to our detailed bedby-bed field observations, four different facies were distinguished as follows:

\subsection{Black shale}

This facies is mainly comprised of black, hard compact shales that appear in massive or finely laminated, laterally continuous beds of thickness ranging from 2 to $20 \mathrm{~cm}$ (Fig. 2B). Laminae, 0.2 to $0.8 \mathrm{~mm}$ thick, are nearly horizontal and mostly continuous, and are defined by changes in their con- 

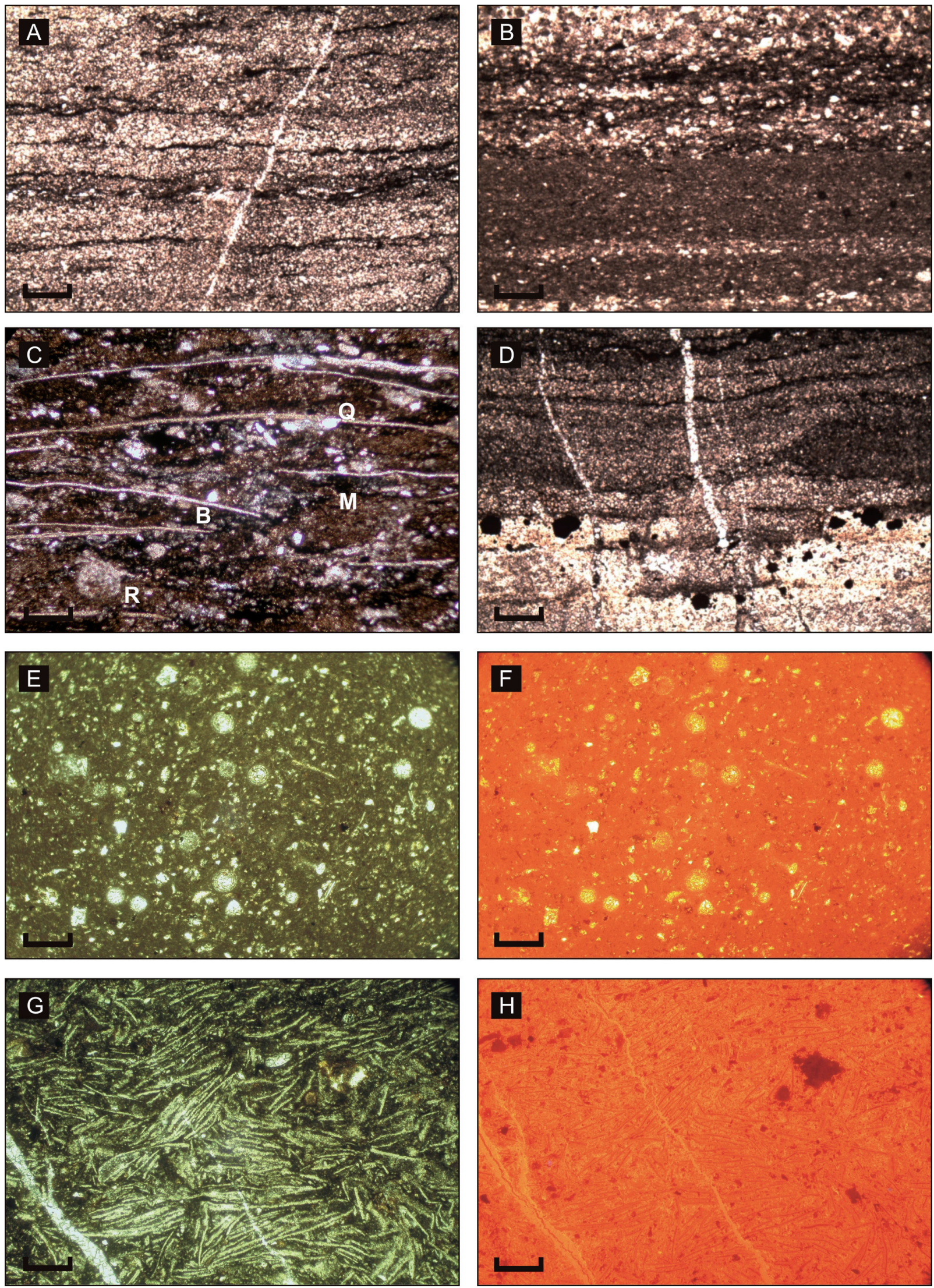

Fig. 3.- A. Microphotograph of laminated lime-mudstone showing a slight alternation of micritic laminae and microsparitic laminae. B. Laminated wackestones showing alternations of dark micritic laminae with microsparitic laminae. C. Bioclastic wackestone containing thin bivalve shells (B), radiolarians (R), dark peloidal micrite (M) and silt quartz grains (Q). D. Thin section of erosive base mudstone-wackestone. Note disseminated pyrite crystals. E, F. Plane-polarized light (left) and the corresponding cathodoluminiscence view (right) of calcitized radiolarians. G, H. Plane-polarized light (left) and the corresponding cathodoluminiscence view (right) of thin bivalve shells. Scale-bar: $0.5 \mathrm{~mm}$. 
tents of clay, tiny pyrite crystals and disseminated organic matter. Subangular to angular silt-size quartz grains may also occur. Bulk X-ray diffraction analysis of four representative samples revealed illite, mixed illite/smectite and kaolinite. Additional components are calcite, quartz, feldspars, and other phyllosilicate minerals. Laminated shales show a gradual transition to laminated mudstones. Carbonate contents of black shales were $1.40 \%$ to $4.33 \%$, whereas TOC averaged $2.77 \%$. Microscopy-recognizable organic materials are consistent with the relatively high organic carbon content of this facies.

\section{Interpretation}

Laminated black shales are interpreted as relatively deep deposits and represent deposition from pelagic and hemipelagic suspension settling on quiet sea floors located probably below storm-wave base. As mentioned by Calvert (1987), a high rate of primary productivity and organic carbon flux to the sea floor could be responsible for deposition of organic rich black-shales.

Their dark colour, general absence of bioturbation and organic content are evidence of oxygen deficient water conditions during deposition (Kauffman and Sageman, 1990; Flügel, 2004). High organic carbon contents and the presence of pyrite framboids also indicate anoxic deposition conditions (Wilkin and Barnes, 1997; Schieber and Baird, 2001).

\subsection{Laminated lime-mudstone}

Laminated lime-mudstones are black and commonly occur as tabular beds up to $15 \mathrm{~cm}$ thick but more commonly 2 to $8 \mathrm{~cm}$ (Fig. 2C). Sometimes, carbonate nodules of diagenetic origin can disrupt this original tabular pattern. These deposits exhibit a delicate, sub-millimetre scale of planar to slightly irregular lamination (Fig. 3A). Randomly distributed (often calcitized) radiolarians are common as well as isolated fragments of thin bivalve shells.

Thin-section observations show an alternation of fine dark organic-matter rich laminae and light-coloured, thicker, carbonate laminae. SEM reveals micrite to microsparitic crystals and the presence of microbial filaments and abundant pyrite framboids.

\section{Interpretation}

Based on observations of outcrops and thin-sections, laminated lime mudstones are interpreted as deposited in an oxygen-deficient, low-energy environment, located probably below storm-wave base. Features such as fine micro-lamination, their dark colour, high organic matter content, and absence of benthic organisms, suggest oxygen-deficient bottom water. In fact, the exceptional quality of laterally continuous laminated deposits points to the absence of burrowers and the absolutely quiet conditions of the depositional environment.
Fine micro-laminations indicate primary sedimentation by pelagic and hemipelagic suspension settling. Similar facies have been reported by Stefani and Burchell (1990) and Longman et al. (1998). The high organic carbon content and occurrence of pyrite indicate anoxic deposition conditions at least in interstitial waters (Wilkin and Barnes, 1997; Schieber and Baird, 2001; Tribovillard et al., 1994).

\subsection{Laminated radiolarian wackestones}

This facies is defined by its dark grey to black colour, usually laminated, fine to medium grained wackestones, which can show normal grading (Fig. 3B). Sharply-defined bases, which appear in individual beds, 5 to $15 \mathrm{~cm}$ thick (Fig. 2D), can also be a significant feature of this facies. Remarkably, Chondrites traces were identified in some intervals.

Radiolarians are the predominant skeletal components of the facies, although thin bivalve shells (Bositra sp.) and sponge spicules are also present and can be abundant locally. Additional allochem particles include pelloids, some spherical single-walled calcispheres, and rare microcrinoid ossicles. Bioclasts (bositras and radiolarians) show a parallel to subparallel orientation to bedding (Fig. 3C), and Bositra shells appear disarticulated and broken. Additional components include micritic peloids, pyrite and iron oxide minerals. The micrite peloids are similar to those described by Chafetz (1986) and Kazmierczak et al. (1996) and are probably related to bacterial induced-precipitation.

SEM imaging of this facies reveals micrite and microsparitic crystals, abundant pyrite framboids and fossil microbial remains. These remains include microbial (bacterial?) filaments (Fig. 4A) and probably also coccoid bacteria (Fig. 4B) within micritic and microsparitic unpitted crystals (Fig. 5A).The facies can therefore be considered typical of lithified calcite-containing mud (Lasemi and Sandberg, 1984; Munnecke et al., 1997).

This facies is common in the middle and top of the sedimentary succession examined. Carbonate ellipsoidal nodules up to $10 \mathrm{~cm}$ in length are scattered amongst the shale and wackestone facies, preferentially located along bedding planes.

\section{Interpretation}

The presence of normal grading, sharp bases and gradational tops suggests deposition from dilute turbidity flows and suspended fine particles. These turbidity flows could result in short periods of increased oxygenation on the sea floor, which would allow colonization by low oxygen-tolerant benthic fauna, as revealed by the presence of Chondrites traces (Ekdale and Mason, 1988; Savrda et al., 1991). This ichnogenus is a structure produced by deposit feeders such as annelids or sipunculoid worms (Richter, 1927; Osgood, 1970), which is communicated with water-sediment interfase and stands restricted oxygen levels (Rhoads and Morse, 1971; Ekdale and Mason, 1988; Savra et al., 1991). Such intervals 
with low but significant oxygen contents would also promote the proliferation of the low-oxygen tolerant bivalve Bositra (see more details below).

It should be noted, however, that precise intervals of oxygenation were always restricted to the dominant anoxic to sub-oxic conditions (Wilkin and Barnes, 1997; Schieber and Baird, 2001) as revealed by their high organic carbon contents, and the occurrence of pyrite framboids and fossil microbial remains. On the other hand, coccoid bacterial-like textures and micritic peloids could be interpreted as having a bacterial origin (Tribovillard, 1998; Perri and Tucker, 2007).

The presence of pyrite framboids (Figs. 4C, 5B) and their distribution in laminated wackestone levels indicate the recurrent development of an anoxic sulphide zone below the sediment surface. Studies on pyrite framboids implicate biogenic processes in their formation (Min et al., 2001). Taylor and Macquaker (2000) argued that pyrite framboids may form during early diagenesis from iron-rich porewaters at sites featuring sulphide, that is, near organic matter, where bacterial sulphate reduction plays a key role.

\subsection{Laminated to massive bioclastic wackestone to packstone}

This facies is characterized by black to greyish black colours and is defined by the accumulation of disarticulated and moderately fragmented shells of the thin-shell bivalve Bositra. Radiolarians and other undifferentiated skeletal debris are subordinated. The allochems are embedded in a micrite matrix, and arranged preferentially parallel to bedding. Phylosilicate clasts, peloids, and pyrite crystals are also present (Fig. 3D). Bioturbation is only locally present, represented by scarce Chondrites traces. It should be noted that this facies is frequently associated with the laminated radiolarian wackestone described above.

The fine, disarticulated bivalve shells that form accumulations in these relatively deep facies have been described frequently in the literature as "filaments". The shells appear disarticulated and exhibit different degrees of fragmentation. Their orientation varies locally, being in general more frequent the valves concordant with bedding planes, and also the oblique ones. These shells show thin calcite crystals in their internal structure, similarly to those identified by Navarro et al. (2009) in the Middle Jurassic deposits of southern Spain.

Shell packing varies between loose (shell percentages 40$75 \%$ ) and dense (shell percentages over $75 \%$ ). Recognizable fragments range in size from $50 \mu \mathrm{m}$ to more than $1000 \mu \mathrm{m}$ and shell density decreases upwards. Due to the nature of the material examined, it is not possible to observe taphonomic features such as bioerosion and incrustation or stratigraphic features such as lateral extension or geometry.

\section{Interpretation}

Sharply defined bases and normal grading are characteristic of these skeletal packstone to wackestone facies and
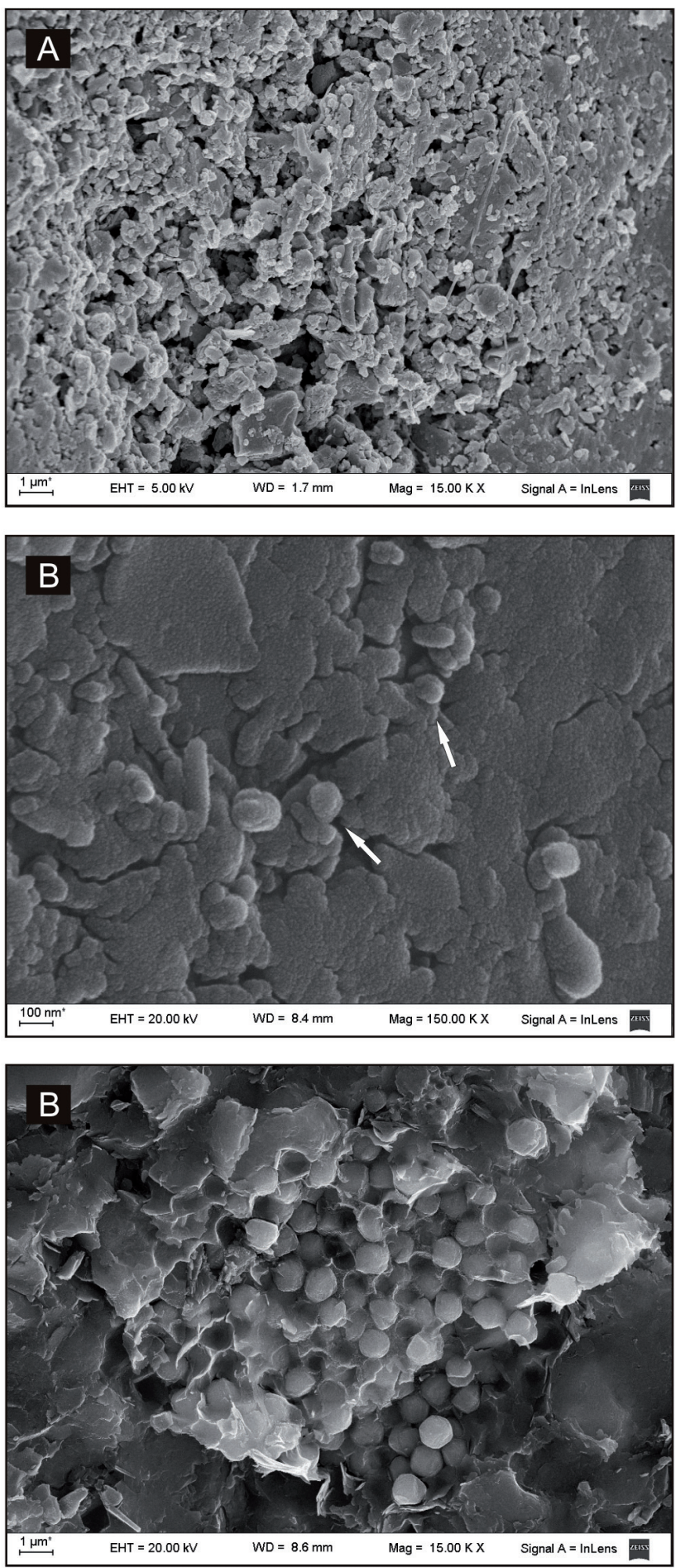

Fig. 4.- A. SEM image of bacterial filaments in an uniform micritic mosaic. B. SEM image of small spheroidal bodies (arrow) in the wackestone facies. Shape and size features resemble probably coccoid bacteria (cf. Schieber and Baird, 2001). C. Framboid pyrite crystals between matrix of wackestone facies (SEM image).

indicate event sedimentation (Flügel, 2004). Normal gradding suggests a decreasing influx of sediments that may have been deposited by dilute turbidity flows and suspended fine grains, sharp basal contacts and gradational upper contacts 
support this interpretation (Cook and Mullins, 1983; Oschmann, 1988; Mulder and Alexander, 2001). These facies were deposited in an oxygen-deficient environment where intermittent energy conditions periodically interrupted periods of lower-energy suspension sedimentation.

As previously mentioned for other facies, radiolarians tests appear replaced by calcite, but some of them have still preserved their original morphology. Photomicrographs illustrate in plane polarized light and CL of radiolarians (Fig. 3E, F) and Bositra shells (Fig. 3G, H). The bright orange/yellow color seen in both views is described as brightly luminescent, which is clearly diagenetic and interpreted as the result of groundwater activity. The dissolution of radiolarian tests was controlled by the silica saturation of the pore fluids (Flügel, 2004).

\subsection{Layers of "filaments"}

Bositra shell accumulations are interpreted as the result of the proliferation of this bivalve during periods of favourable environmental conditions on the sea floor. Disarticulation, fragmentation, and reorientation of valves can be indicative of some reworking, probably by weak currents affecting the sea floor. However, as Rivas et al. (1997) suggest, breaking and reorientation of thin bivalve shells can be produced by mechanical compaction during burial.

The presence of monospecific filaments of Bositra with Chondrites and the absence of shelly infauna indicate anoxic conditions in interstitial waters and poorly oxygenated conditions in bottom waters. Short improvements in bottom conditions would have allowed the settlement of Bositra, which is an r-strategist (Pianka, 1970). Oxygen supply was probably the main factor controlling benthic colonization.

The presence of Bositra was reported in the Neuquén Basin since the middle Toarcian to the Callovian interval (Damborenea, 1987). The genus appears commonly associated with black shales, such as those described in the Oxfordian deep-ramp facies of this paper. Bositra has an epifaunal benthic life style (Duff, 1978; Oschmann, 1993; Bottjer and Savrda, 1993; Etter, 1996; Röhl et al., 2001; among others). This genus is tolerant to low oxygen conditions (Caswell et al., 2009), and maximum abundances occurred when oxygen levels restricted the settling of other taxa but before the bottom water was extremely oxygen-depleted (Etter, 1996). Its settlement would occur during reoxygenation, with the redox boundary located at the sediment-water interface, allowing colonization by epifaunal but not infaunal organisms (Caswell et al., 2009).

\section{Depositional system}

La Manga Formation deposits developed as a widespread carbonate system in which shallow and middle ramp deposits predominate (Legarreta, 1991; Palma et al., 2007). However, Arroyo Los Blancos section mainly represents suspended-

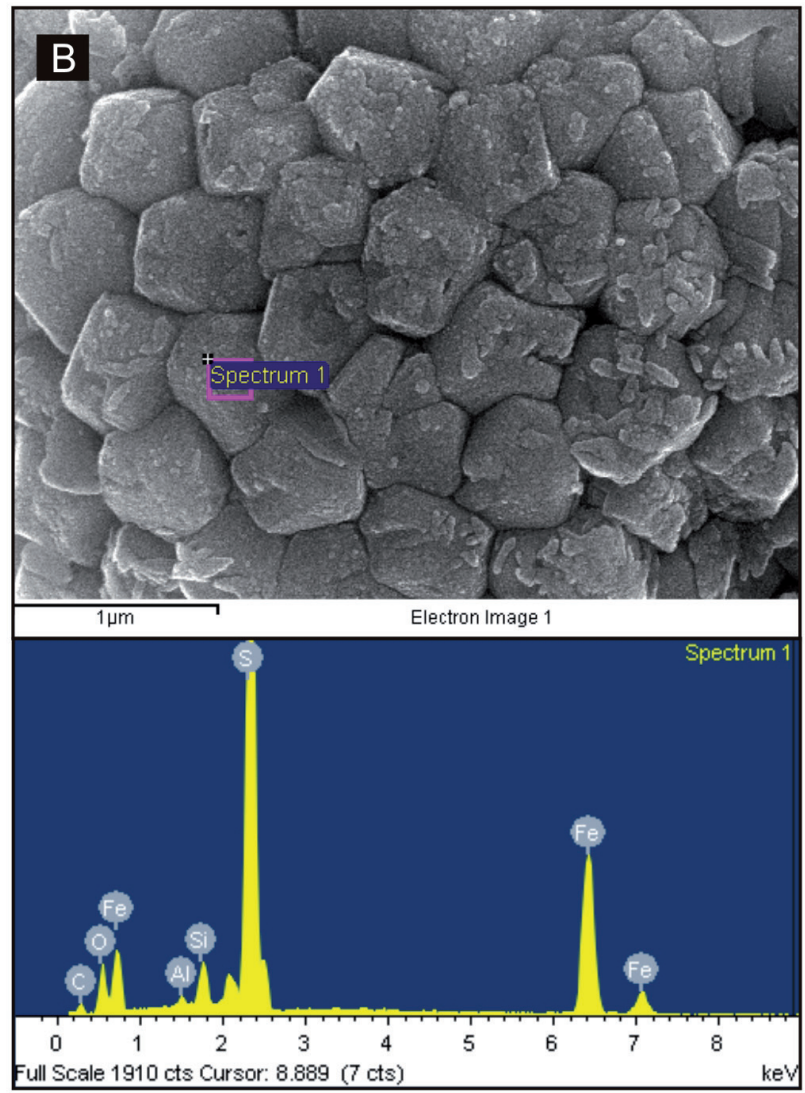

Fig. 5.- A. SEM view of micritic and microsparitic crystals and EDAX spectrum. B. SEM image of typical submicron-size crystals of framboid pyrite and EDAX spectrum. 


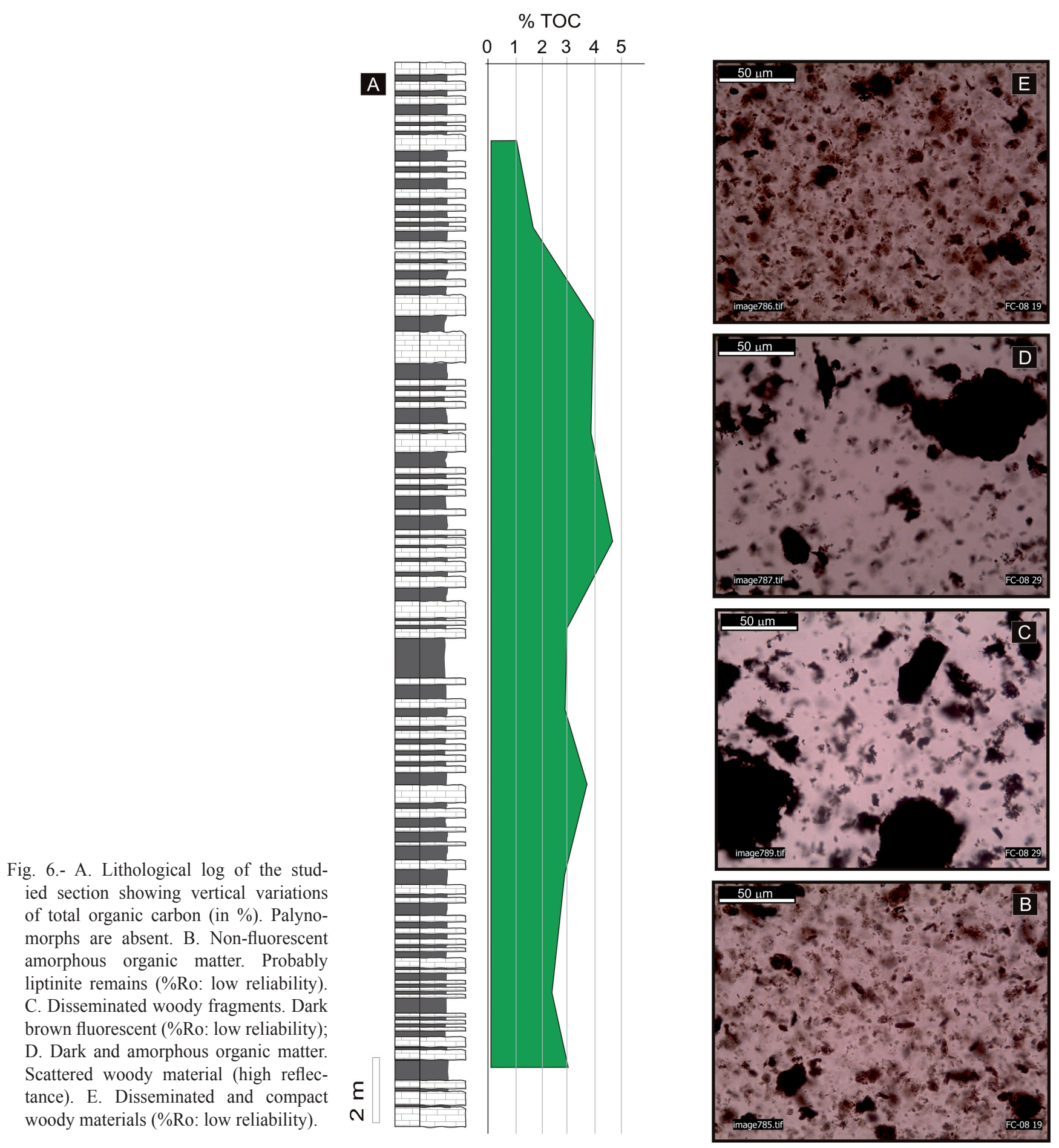

load deposition below the storm wave base, under conditions of generally low, although fluctuating, bottom shear stress. Rhythmic variations in carbonate contents could be explained by fluctuations in the primary production of carbonate at shallow settings.

Conditions of low oxygenation prevailed during sedimentation, and a state of anoxia was likely reached in many time intervals, as suggested by the lack of bioturbation and the presence of pyrite crystals in the dominant facies. Non bioturbated laminated black shale indicate that oxygen levels beneath and just above the sediment-water interface were too low to support a burrowing infauna. Episodic winnowing is documented by skeletal accumulations of thin-shelled bivalves (Bositra sp.). The absence of shallow-water fauna and the frequent abundance of planktonic fauna indicate relatively deep, hemipelagic conditions.

\section{Source rock evaluation}

Total organic carbon (TOC) contents in the Arroyo Los Blancos section ranged from 0.88 to $4.33 \%$ (Fig. 6A), while the maximum hydrogen index (HI) was only $2 \mathrm{mg} \mathrm{HC} / \mathrm{g}$ TOC. 

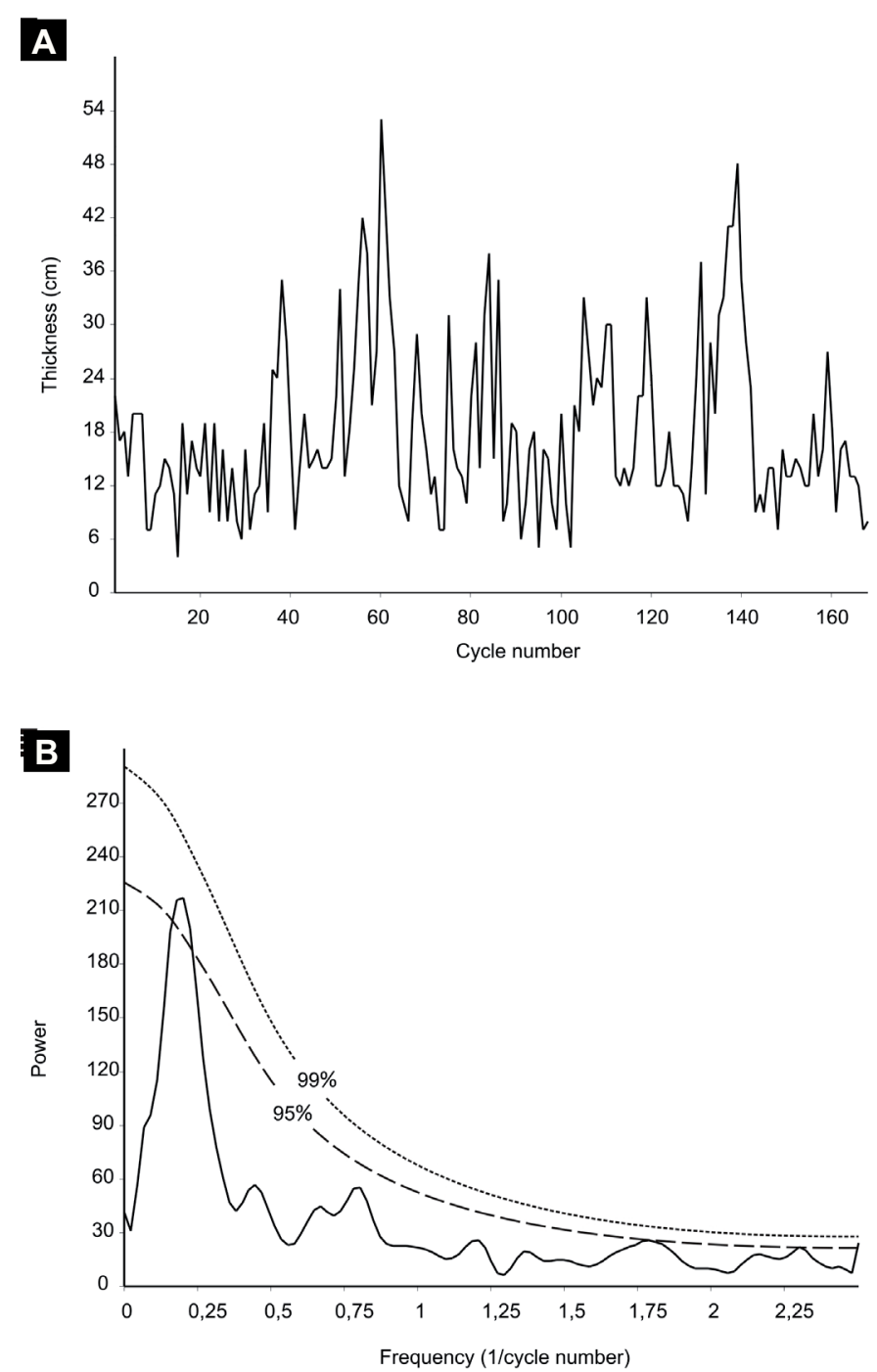

Fig. 7.- A. Time series of Arroyo Los Blancos section constructed from thickness of elementary cycles. B. Blackman-Tuckey spectrum, showing the presence of the high frequency excentricity cycle. Confidence levels are indicated in dotted lines.

TOC contents were compared with TOCs also obtained by us in the same stratigraphic interval but in Arroyo La Manga (see Fig. 1), $40 \mathrm{~km}$ north of the Arroyo Los Blancos. Arroyo La Manga Formation section consists of outer ramp facies (Palma et al., 2010), i.e., deposits clearly shallower than those herein considered. Noticeably, TOC contents for Arroyo La Manga varied only from $0.05 \%$ to $1.98 \%$, yielding a markedly lower average.

These differences can be interpreted in terms of a higher (and more homogeneous through time) oxygenation of the sea bottom in the case of Arroyo La Manga, where relatively higher oxygen levels would have caused the faster degradation of organic matter. This theory is consistent with the dominant facies and palaeontological contents of Arroyo La Manga.

Pyrolysis data derived from the Arroyo Los Blancos section also attributed to black shale samples moderate to high amounts of organic matter (Fig. 6B-E), and identified types $\mathrm{IV}$ and III as the main kerogen types. Pyrolysis S values were low, which together with the low hydrogen indices obtained, suggest poor kerogen convertibility. Organic petrography revealed little to null fluorescence properties of disseminated amorphous dark-brown organic matter (fluorescence scale after Tyson, 1995).

The low $\mathrm{S}$ values and high TOC detected in the samples examined suggest the presence of hydrogen at low concentrations and overly mature organic matter. $\mathrm{T}_{\max }$ pyrolisis data $\left(410^{\circ} \mathrm{C}\right.$ and $\left.450^{\circ} \mathrm{C}\right)$ did not indicate significant changes in maturity. Vitrinite reflectance (\%Ro) was 2.39 to 2.97 , with an average of 2.70 , while the thermal alteration index (TAI) was $4+(5)$, also indicating over-mature stages.

\section{Cyclostratigraphic analysis}

According to its vertical facies variations, in the Arroyo Los Blancos section is recognized a notable rhythmicity. Our observations indicate a well-ordered hierarchy of cycles, manifesting as elementary cycles and bundles of cycles. Elementary cycles show a relatively regular thickness in the order of 5 to $30 \mathrm{~cm}$ and an average thickness of $16.5 \mathrm{~cm}$.

The rhythmicity observed was characterized through a cyclostratigraphic analysis. This entails differentiating $\mathrm{cm}$-scale facies couplets considered as elementary cycles (rhythms) that represent approximately equivalent time durations. According to our biostratigraphic data, the section of La Manga Formation examined covers the early to middle Oxfordian age $(\sim 3.5 \mathrm{Ma})$. Dividing the duration of the time interval by the number of elementary cycles distinguished gives an average duration of each cycle of $20.8 \mathrm{ky}$. This value is in the range of the precessional cycle of the Earth's orbit.

The chosen variable for the study was rhythm thickness, and variations in this variable through the stratigraphic section (Fig. 7A) were assessed by spectral analysis for the detection of larger scale (lower frequency) cyclicities. Similar approaches for this purpose have been described in the literature (e.g., Goldhammer et al. 1990; Schwarzacher, 1993; Lehmann et al., 1998; Raspini, 2001; Anderson, 2004; Strasser et al., 2004; among others).

The Blackman-Tuckey spectrum for the thickness series is shown in Figure 7B. The spectrum shows a marked peak (above the 95\% confidence level) corresponding to 4.5 elementary cycles ( $\sim 94 \mathrm{ky})$. This periodicity can be attributed to the high frequency eccentricity cycle of the Earth's orbit.

Our data thus suggest that the rhythmicity identified in the La Manga Formation of the Arroyo Los Blancos section can be attributed to environmental changes controlled by regional climate variations. In turn, these variations would have been modulated by the orbital parameters equinoctial precession and eccentricity. Data from other Jurassic deposits are consistent with this rhythmicity and interpretation (e.g., Weedon et al., 1999; Strasser et al., 2004; Husinec and Read, 2007). 


\section{early Callovian to middle Oxfordian}

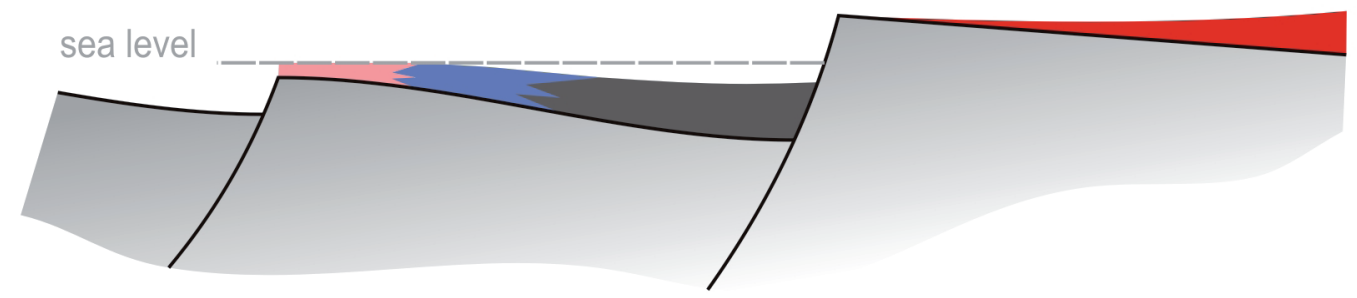

middle to late Oxfordian

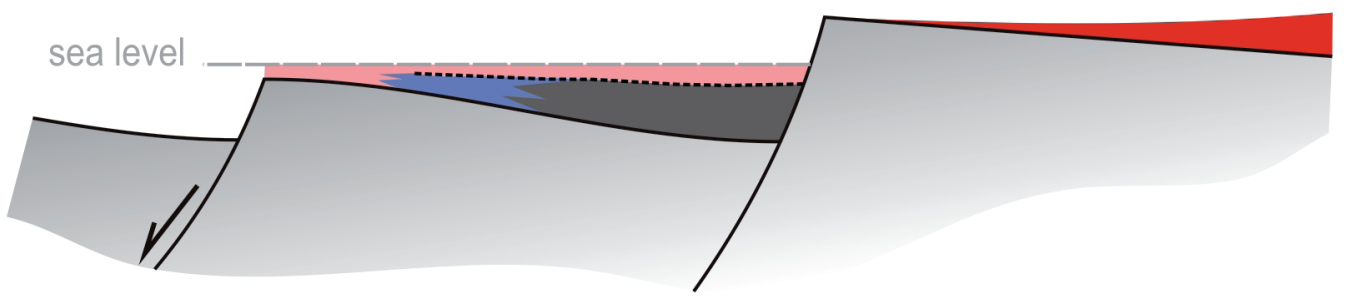

Inner ramp peritidal facies

\section{Outer ramp facies}

\section{Deep marine basinal facies}

\section{Continental facies}

Fig. 8.- Block diagram of the Los Blancos area showing different subsident blocks and depositional environments of the La Manga Formation.

\section{Tectono-sedimentary model}

The Oxfordian in the Neuquén Basin was characterized by the development of a broad carbonate ramp represented by La Manga Formation (Legarreta 1991; Palma et al. 2007). In this ramp, both facies patterns and accumulation rates varied spatially and temporarily, mainly in response to eustatic and tectonic factors. Eustatic changes have been explored in studies examining the shallow sedimentary successions of this unit (Palma et al., 2007). However, understanding tectonic controls requires a different approach whereby local changes in deposit thickness and facies patterns need to be considered.

Despite the dominance of shallow water carbonates over vast areas of the basin, a tectonically inherited palaeotopography, as well as synsedimentary fault-controlled block movements, seem to have determined the existence of areas of notably greater water-depths, in which the prevailing sedimentary conditions were hemipelagic. This is the case of the Arroyo Los Blancos area, where local deep-water facies deposition prevailed during the middle Oxfordian. Neighbouring areas show notable palaeoceanographic differences. The relatively deep marine deposits of Arroyo Los Blancos have also been observed in areas such as Yeseras Grandes.
However, in zones close to Arroyo La Manga and Codo del Blanco (Palma et al., 2012, 2013) time-equivalent deposits correspond to outer ramp facies.

Interestingly, in all outcrops, the deposits of the top of $\mathrm{La}$ Manga Formation are characterized by low-energy, subtidal and peritidal facies (Palma et al., 2013), showing a sharp, non-transitional, contact between deep marine/outer ramp deposits and peritidal deposits. This probably reflects an interval of rapidly decreasing accommodation causing a regional forced regression (Palma et al., 2010, 2013).

The tectono-sedimentary framework for the deposits of Arroyo Los Blancos and nearby areas is modelled in figure 8 . In the model, the relatively deep, organic matter-rich facies of La Manga Formation would have been deposited in the deeper areas of topographic lows, where bathymetric and environmental constraints determined their accumulation and preservation. These topographic lows were controlled by tilting and differential subsidence of tectonic blocks bounded by normal (listric) faults, probably inherited from previous extensional tectonics of Late Triassic - Early Jurassic age.

This palaeo-topographic landscape of highs and lows would have controlled both local maximums of water-depth and the confining of deep waters. Such deep waters were 
subjected to stratification, starving and, in consequence, the installation of dysaerobic to anaerobic environmental conditions at the sea bottom. These conditions were dominant for nearly $3.2 \mathrm{~m} . \mathrm{y}$., allowing the accumulation of large amounts of organic-matter.

Organic matter contents of 1.20 to $4.53 \%$ were recorded in Arroyo Los Blancos (versus 2\% maximum for the outer ramp facies of Arroyo La Manga). Although our vitrinite reflectance, thermal alteration index and pyrolysis $\left(\mathrm{T}_{\max }\right)$ data indicate overmature stages in the Atuel depocenter, in other locations of the basin, these deep marine facies could be excellent source rocks, as well as excellent unconventional reservoirs (shale-gas/oil). In effect, organic matter-rich facies and the remarkable orbital-controlled rhythmicity of these deposits, resemble those of the Tithonian-Valanginian Vaca Muerta Formation (e.g., Kietzmann et al., 2011, 2014) that constitutes the main unconventional oil reserve of the Neuquén Basin.

\section{Conclusions}

La Manga Formation (Callovian-Oxfordian) represents the development of a vast carbonate ramp in the Neuquén Basin, which is characterized by the dominance of shallow and middle ramp deposits. However, in tectonically controlled settings, deeper deposits also exist, and these feature organic matter-rich facies of possible economic interest. The key points emerging from this study of the succession of these relatively deep deposits in Arroyo Los Blancos (southern Mendoza Province) are:

1) The sedimentation mechanism was mainly suspendedload deposition on quiet sea floors located probably below storm-wave base. Low oxygenation conditions prevailed during sedimentation, and a state of anoxia was reached across several time intervals, as suggested by the presence of: a) organic-rich shales, b) undisrupted lamination in most facies, c) pyrite framboids, and d) absence or scarcity of trace fossils and benthic fauna. Only isolated Chondrites and occasional low-oxygen tolerant bivalves (Bositra sp.) were detected. Thin graded beds of wackestones and accumulations of slightly reworked shells of bivalves suggest sporadic reworking of the sea floor by weak currents.

2) Carbonate contents vary throughout the section, probably as the consequence of changes in the primary production of carbonate at shallow settings. Cyclostratigraphic analysis of this feature suggests that these variations were controlled by environmental/climate changes consistent with the Earth's orbital parameters of precession and eccentricity.

3) TOC contents and different types of organic matter were assessed by organic petrology, Rock-Eval pyrolysis and thermal maturity indicators. The low pyrolysis $\mathrm{S}$ yields accompanied by low hydrogen indices observed suggest poor kerogen convertibility. Vitrinite reflectance (\%Ro) was 2.39 to 2.97 , averaging at 2.70 , while the thermal alteration index (TAI) was $4+(5)$, indicating overmaturity.
4) The model for the tectono-sedimentary framework of the succession and neighbouring areas proposed here suggests that the relatively deep organic matter-rich facies of the La Manga Formation were deposited in the deepest areas of topographic lows, where bathymetric and environmental constraints determined their accumulation and preservation. These topographic lows were controlled by tilting and differential subsidence of tectonic blocks bounded by normal (listric) faults, probably inherited from previous extensional tectonics of Late Triassic - Early Jurassic age.

\section{Acknowledgements}

This research was supported by the Consejo Nacional de Investigaciones Científicas y Técnicas (PIP-0546), the Agencia Nacional de Promoción Científica y Tecnológica (PICT2542) and the Universidad de Buenos Aires (UBACyT 01/ $\mathrm{XC28)}$ and as well as the Research Groups 910198 and 910429 (UCM-Comunidad de Madrid, Spain). Thanks are given to Juan C. Poblete for their assistance in field work. The comments by two anonymous referees are also geatly appreciated. his is the contribution R-137 of the Instituto de Estudios Andinos Don Pablo Groeber (IDEAN).

\section{References}

Anderson, E.J. (2004): The cyclic hierarchy of the "Purbeckian" Sierra del Pozo Section, Lower Cretaceous (Berriasian), southern Spain. Sedimentology 51, 455-477. doi: 10.1111/j.1365-3091.2004.00632.x

Bottjer, D., Savrda, C. (1993): Oxygen-related mudrocks biofacies. Sedimentology Review 1, 92-102. doi: 10.1002/9781444304534.ch6

Calvert, S. (1987): Oceanographic controls on the accumulation of organic matter in marine sediments. In: J. Brooks, A.J. Fleet (eds.), Marine Petroleum Source Rocks. Geol. Soc. London Spec. Publ., 26, Blackwell, London, pp. 137-151.

Caswell, B.A., Coe, A.L., Cohen, A.S. (2009): New range data for marine invertebrate species across the early Toarcian (early Jurassic) mass extinction. J. Geol. Soc. London 166, 859-872. doi: 10.1144/001676492008-0831.

Cook, H.E., Mullins, H.T. (1983): Basin margin. In: P.A. Scholle, D.G Bebout, C.H. Moore (eds.), Carbonate Depositional Environments. AAPG Mem., 33, 539-618.

Chafetz, H.S. (1986): Marine peloids: a product of bacterially induced precipitation of calcite. Journal of Sedimentary Petrolology 56, 812816.

Damborenea, S.E. (1987): Early Jurassic bivalvia of Argentina. Part 2: Superfamilies Pteriacea, Buchiacea and part of Pectinacea. Palaeontographica Abt. A 199, 113-216.

Digregorio, J.H. (1965): Informe preliminar sobre la ubicación estratigráfica de los Estratos Marinos Subyacentes en la Cuenca neuquina. Acta Geológica Lilloana 7, 119-146.

Duff, K.L. (1978): Bivalvia from the English Lower Oxford Clay (Middle Jurassic). Palaeontographical Society Monographs, 553p.

Ekdale, A.A., Mason, T.R (1988): Characteristic trace-fossils associations in oxygen-poor sedimentary environments. Geology 16, 720 723.

Espitalié, J., Deroo, G., Marquis, F. (1985): La pyrolyse Rock Eval et ses applications. Rev. Instit. Fr. Pétr. 40, 563-579.

Etter, W. (1996): Pseudoplanktonic and benthic invertebrates in the Middle Jurassic Opalinum Clay, northern Switzerland. Palaeogeogra- 
phy, Palaeoclimatology, Palaeoecology 126, 325-341. doi: 10.1016/ S0031-0182(96)00036-3.

Flügel, E. (2004): Microfacies of carbonate rocks. Springer-Verlag, New York, 983 p.

Giambiagi, L., Bechis, F., Lanés, S., Tunik, M., García, V., Suriano, J., Mescua, J. (2008): Formación y evolución Triásico-Jurásica del depocentro Atuel, Cuenca Neuquina, provincia de Mendoza. Revista de la Asociación Geológica Argentina 63, 520-533.

Goldhammer, R.K., Dunn, P.A. y Hardie, L.A. (1990): Depositional cycles, composite sea-level changes, cycle stacking patterns, and the hierarchy of stratigraphic forcing. Geological Society of America Bulletin 102, 535-562.

Husinec, A., Read, J.F. (2007): The Late Jurassic Tithonian, a greenhouse phase in the Middle Jurassic-Early Cretaceous "cool" mode: Evidence from the cyclic Adriatic platform, Croatia. Sedimentology 54, 317-337. doi: 10.1111/j.1365-3091.2006.00837.x

Kauffman, E.G., Sageman, B.B. (1990): Biological sensing of benthic environments in dark shales and related oxygen-restricted facies. In: R.N. Ginsburg, B. Beaudoin (eds.), Cretaceous resources, events and rhythms, Kluwer Academic Publishers, Dordrecht, pp. 121-139.

Kazmierczak, J., Coleman, M.L., Gruszczynski, M., Kempe, S. (1996): Cyanobacterial key to the genesis of micritic and peloidal limestones in ancient seas. Acta Palaeontologica Polonica 41, 319-338.

Kietzmann, D.A., Martín-Chivelet, J., Palma, R.M., López-Gómez, J., Lescano, M., Concheyro, A. (2011): Evidence of precessional and eccentricity orbital cycles in a Tithonian source rock: the mid-outer carbonate ramp of the Vaca Muerta Formation, Northern Neuquén Basin, Argentina. AAPG Bulletin 95, 1459-1474. doi: 10.1306/01271110084

Kietzmann, D.A., Palma, R.M., Riccardi, A.C., Martín-Chivelet, J., López-Gómez, J. (2014): Sedimentology and sequence stratigraphy of a Tithonian - Valanginian carbonate ramp (Vaca Muerta Formation): A misunderstood exceptional source rock in the Southern Mendoza area of the Neuquén Basin, Argentina. Sedimentary Geology 302, 64-86. doi: 10.1016/j.sedgeo.2014.01.002

Lasemi, Z., Sandberg, P.A. (1984): Transformation of aragonite-dominated lime muds to microcrystalline limestones. Geology 12, 420-423.

Legarreta, L. (1991): Evolution of a Callovian-Oxfordian carbonate margin in the Neuquen Basin of the west-central Argentina: facies, architecture, depositional sequences and global sea-level changes. Sedimentary Geology 70, 209-240.

Legarreta, L., Gulisano, C.A. (1989): Análisis estratigráfico secuencial de la Cuenca Neuquina (Triásico Superior- Terciario Inferior), Argentina. In: G.A. Chebli, L.A. Spalletti, (eds.), Cuencas Sedimentarias Argentinas. Simposio Cuencas Sedimentarias Argentinas, Serie Correlación Geológica 6, pp. 221-243.

Legarreta, L., Uliana, M.A. (1996). The Jurassic succession in west central Argentina: Stratal patterns, sequences, and paleogeographic evolution. Palaeogeography, Palaeoclimatology, Palaeoecology 120, 303-330. doi: 10.1016/0031-0182(95)00042-9.

Lehmann, C., Osleger, D.A., Montañez, I.P. (1998): Controls on cyclostratigraphy of Lower Cretaceous carbonates and evaporites, Cupido and Coahuila platforms, Northeastern Mexico. Journal of Sedimentary Research 68, 1109-1130.

Longman, M.W., Luneau, B.A., Landon, S.M. (1998): Nature and distribution of Niobrara lithologies in the Cretaceous Western Interior Seaway of the Rocky Mountain Region. The Mountain Geologist 35(4), 137-170.

Min, M.Z ., Luo, X.Z., Mao, S.L., Wang, Z.Q., Wang, R.C., Qin, L.F., Tan. X.L. (2001): An excellent fossil wood cell texture with primary uranium minerals at a sandstone-hosted roll-type uranium deposit, NW China. Ore Geology Reviews 17, 233-239. doi: 10.1016/S01691368(00)00007-X

Mitchum Jr., R.M., Uliana, M.A. (1985). Seismic stratigraphy of carbonate depositional sequences, Upper Jurassic-Lower Cretaceous.
Neuquén Basin, Argentina. In: R.B. Berg, \& D. G. Woolverton (eds), Seismic Stratigraphy: an integrated Approach to Hydrocarbon Exploration. American Association of Petroleum Geologists, Memoir, 39: 255-274.

Mulder, T., Alexander, J. (2001): The physical character of subaqueous sedimentary density flows and their deposits. Sedimentology 48, 269299. doi: 10.1046/j.1365-3091.2001.00360.x

Munnecke, A., Westphal, H., Reijmer, J.J.G., Samtleben, C. (1997). Microspar development during early marine burial diagenesis: a comparison of Pliocene carbonates from the Bahamas with Silurian limestones from Gotland (Sweden), Sedimentology 44, 977-990.

Navarro, V., Molina, J.M., Ruiz Ortiz, P.A. (2009): Filament lumachelle on top of Middle Jurassic oolite limestones: event deposits marking the drowing of a Tethysian carbonate platform (Subbetic, southern Spain, Facies 55(1), 89-102. doi: 10.1007/s10347-008-0158-0

Oschmann, W. (1988): Kimmeridge Clay sedimentation - a new cyclicity model. Palaeogeography, Palaeoclimatology, Palaeoecology 65, 217-251. doi: 10.1144/0016-764903-089

Oschmann, W. (1993): Environmental oxygen fluctuations and the adaptive response of marine benthic organisms, Journal of the Geological Society of London 150, 187-191.

Osgood Jr., R.G. (1970): Trace fossils of the Cincinnati area. Palaeontographica Americana 6, 281-444.

Palma, R.M., López-Gómez, J., Piethé, R.D. (2007). Oxfordian ramp system (La Manga Formation) in the Bardas Blancas area (Mendoza Province), Neuquén Basin, Argentina: facies and depositional sequences. Sedimentary Geology 195, 113-134. doi: 10.1016/j.sedgeo.2006.07.001

Palma, R.M., Kietzmann, D.A., Adamonis, S., López-Gómez, J., (2009). Oxfordian reef architecture of the La Manga Formation, Neuquén Basin, Mendoza Province, Argentina. Sedimentary Geology 221, $127-$ 140. doi: 10.1016/j.sedgeo.2009.09.004

Palma, R. M., Kietzmann, D. A., Martín-Chivelet, J., López-Gómez J., Bressan, G. S. (2010): Lower Callovian-Middle Oxfordian facies from the La Manga Formation carbonate ramp: a forced regression. Atuel Depocenter, Neuquén Basin, Mendoza Province, Argentina. The $8^{\text {th }}$ International Congress on the Jurassic System, Sichuan, China, Earth Science Frontiers 17, 302-303.

Palma, R.M., Riccardi, A.C., Kietzmann, D.A., Martín-Chivelet, J., López-Gómez, J., Bressan, G.S. (2011). Depósitos carbonáticos de la Formación La Manga (Caloviano inferior - Oxfordiano medio): evidencias de regresión forzada. Depocentro Atuel, Mendoza, Cuenca Neuquina. XVIII Congreso Geológico Argentino, Actas CD, p. $907-$ 908.

Palma, R.M., Kietzmann, D.A., Martín-Chivelet, J., López-Gómez, J., Bressan, G.S. (2012): New biostratigraphic data from the CallovianOxfordian La Manga Formation, Neuquén Basin, Argentina: Evidence from an ammonite condensed level. Revue de Paléobiologie 11, 345-356. doi: 10.1016/0037-0738(91)90142-Z

Palma, R.M., Kietzmann, D.A., Bressan, G.S., Martín-Chivelet, J., López-Gómez, J., Farias, M.E., Iglesia Llanos, M.P. (2013). Peritidal cyclic sedimentation from La Manga Formation (Oxfordian), Neuquén Basin, Mendoza, Argentina. Journal of South American Earth Sciences 47, 1-11. doi: 10.1016/j.jsames.2013.05.008

Pardo-Igúzquiza, E., Rodríguez-Tovar, F.J. (2004): POWGRAF2: a computer program for graphical spectral analysis. Computers \& Geosciences 30, 533-542. doi: 10.1016/j.cageo.2012.06.002

Perri, E., Tucker, M. (2007): Bacterial fossils and microbial dolomite in Triassic stromatolites. Geology 35, 207-210.

Pianka, E. R. (1970): On $r$ and K selection. American Naturalist 104: 592-597.

Raspini, A. (2001): Stacking pattern of cyclic carbonate platform strata: Lower Cretaceous of southern Appennines, Italy. Journal of the Geological Society 158, 353-366. doi: 10.1144/jgs.158.2.353 
Riccardi, A.C. (2008): The marine Jurassic of Argentina: a biostratigraphic framework. Episodes 31(3), 326-335.

Richter, R. (1927): die fossilen Fährten und Bauten der Würmer, ein uberblick über ihre biologischen Grundform und deren geologische Bedeutung. Paläontologische Zeitschrift 9, 193-240.

Rhoads, D.C., Morse J.W. (1971): evolutionary and ecologic significance of oxygen-deficient basins. Lethaia 4, 413- 428.

Rivas, P., Aguirre, J., Braga, J.C. (1997): Entolium beds - hiatal shell concentrations in starved pelagic settings (Middle Liassic, SE Spain). Eclogae Geologicae Helvetiae 90(2), 293-301.

Röhl, H-J., Schmid-Röhl, A., Oschmann, W., Frimmel, A., Schwark, L. (2001): The Posidonia Shale (Lower Toarcian) of SW-Germany: an oxygen-depleted ecosystem controlled by sea level and palaeoclimate. Palaeogeography, Palaeoclimatology, Palaeoecology 165, 2752. doi: 10.1016/S0031-0182(00)00152-8

Savrda, C.E., Bottjer, D.J., Seilacher, A. (1991): Redox-related benthic events. In: G. Einsele, W. Ricken, A. Seilacher (eds.), Cycles and events in Stratigraphy, Springer, Berlin, pp. 524-541.

Schieber, J., Baird, G. (2001): On the origin and significance of pyrite spheres in Devonian black shales of North America. Journal of Sedimentary Research 71, 155-166.

Schlanger, S.O., Jenkins, H.C. (1976): Cretaceous anoxic events; Causes and consequences. Geol. Mijnbouw. 55, 179-184.

Stefani, M., Burchell, M. (1990): Upper Triassic (Rhaetic) argillaceous sequences in northern Italy: Depositional dynamics and source potential. In: A.Y. Huc (ed.), Deposition of organic facies, AAPG Studies in Geology 30, pp. 93-107.

Stipanicic, P.N. (1966): El Jurásico en Vega de la Veranada (Neuquén), el Oxfordiano y el distrofismo Divesiano (Agassiz-Yaila) en Argentina. Revista de la Asociación Geológica Argentina 20(4), 403-478.

Strasser, A., Hillgärtner, H., Pasquier, J.B. (2004): Cyclostratigraphic timing of sedimentary processes: An example from the Berriasian of the Swiss and French Jura Mountains. In: B. D'Argenio, A.G. Fischer, I. Premoli Silva, H. Weissert, V. Ferreri, (eds.), Cyclostratigraphy: Approaches and Case Histories, SEPM Special Publication 81, pp. 135-151.

Schwarzacher, W. (1993): Cyclostratigraphy and the Milankovitch theory. Elsevier, Amsterdam, 225 p.

Taylor, K.G., Macquaker, J.H.S. (2000): Early diagenetic pyrite morphology in a mudstone-dominated succession; the Lower Jurassic Cleveland Ironstone Formation, eastern England. Sedimentary Geol. 131, 77-86.

Tribovillard, N. (1998): Bacterially mediated peloids in laminated organic-matter rich limestones: an unobtrusive presence. Terra Nova $10,126-130$

Tribovillard, N., Desprairies, A., Lallier-Verges, E., Bertrand, P. (1994). Sulfur incorporation of lipidic organic matter in reactive-iron deficient environments: a possible enhancement for the storage of hydrogen-rich organic matter. C. R. Acad.Sci. Paris 319, 1199-1206.

Tyson, R.V. (1995). Sedimentary organic matter, facies and palynofacies. Chapman \& Hall, New York, 652 p.

Vergani, G., Tankard, A.J., Belotti, H.J., Welsnik, H.J. (1995): Tectonic evolution and paleogeography of the Neuquén basin. In: A.J. Tankard, R. Suárez Sorucco, H.J. Welsnik (eds.). Petroleum Basins of South America, American Association of Petroleum Geologists Memoir 62, pp. 383-402.

Weedon, G.P., Jenkyns, H.C., Coe, A.L. y Hesselbo, S.P. (1999): Astronomical calibration of the Jurassic time scale from cyclostratigraphy in British mudrock formations. Philosophical transactions of the Royal Society A: Mathematical, Physical and Engineering Sciences 357 (1757), 1787-1813.

Wilkin, R.T., Barnes, H.I. (1997): Formation processes of framboidal pyrite. Geochimica et Cosmochimica Acta 61, 323-339. 